\title{
Diversity within subterranean clover and biserrula for persistence traits with potential use in New Zealand hill country
}

\author{
K. GHAMKHAR ${ }^{1,2,3}$, T. FAITHFUL ${ }^{4}$, P.G.H. NICHOLS ${ }^{4,5}$ and M. H. RYAN ${ }^{4}$ \\ ${ }^{1}$ AgResearch Ltd, Grasslands Research Centre, Palmerston North, New Zealand \\ ${ }^{2}$ Centre for Plant Genetics and Breeding, The University of Western Australia \\ ${ }^{3}$ Gin Silico Pty Ltd, PO Box 1159, Blackburn North, VIC, 3130, Australia \\ ${ }^{4}$ Institute of Agriculture and School of Plant Biology, The University of Western Australia, Australia \\ ${ }^{5}$ Department of Agriculture and Food Western Australia, South Perth, WA, Australia
}

kioumars.ghamkhar@agresearch.co.nz

\begin{abstract}
As part of an investigation into the potential of alternative forage species and/or germplasm in New Zealand's hill country and the traits required for their success, two F2 populations, their original parents, and 34 cultivars of subterranean clover (Trifolium subterranean) were evaluated for hardseededness in Australia. The 34 cultivars were also screened for burr burial strength and flowering time. Microsatellite markers were also used to investigate their association with these traits. The polygenic nature of hardseededness was confirmed and markers associated with this trait were detected and traits for New Zealand's hill country were identified. Additionally, a core collection of 30 (two cultivars and 28 wild) biserrula (Biserrula pelecinus) accessions was screened for flowering time, growth habit and leaflet size. Also, a subset of five accessions of biserrula exhibited traits that are desirable for hill country, namely, mid-late flowering and adaptation to lowmedium rainfall.
\end{abstract}

Keywords: biserrula, flowering time, hardseededness, hill country, subterranean clover

\section{Key messages}

- Molecular markers may help in selection for future soft-seeded subterranean clovers

- Low and high burr burial should be screened in subterranean clover core collection for a balance between persistence and economically and environmentally viable seed harvest

- Biserrula is a new candidate species for summer dry hill country and five accessions of this species have desirable traits for this region.

\section{Introduction}

There are many constraints to pasture productivity in the hill country of New Zealand, including the effect of slope on the infiltration of water into an often shallow soil profile, which reduces rainfall effectiveness and total plant available water. This results in plant moisture stress. This type of drought is not necessarily due to the lack of precipitation but rather the high rate of water flow and/or a high evaporation/transpiration ratio (Feldhake \& Boyer 1990; Lambert \& Roberts 1976; Maxwell et al. 2010; Radcliffe \& Lefever 1981). At the forefront of solutions to this problem is the introduction of new species, or new germplasm of current species, that are more likely to tolerate this environment, as past introductions have had varying success (Barker et al. 1993; Charlton \& Belgrave 1992; Nichols et al. 2016).

Subterranean clover (Trifolium subterraneum) (sub clover) is the best annual self-regenerating and predominantly self-fertile/inbred clover species in grass-based perennial pastures of New Zealand (Lucas et al. 2015) and has been recommended for New Zealand's moist and dry hill country (Charlton \& Stewart 1999; Dodd et al. 1995; Suckling et al. 1983). Many traits have been investigated to increase productivity of sub clover in the hill country, with seed set and grazing-tolerant morphology shown to be highly desirable (Chapman \& Williams 1990; Widdup \& Pennell 2000). However, a subset of three sub clover traits are likely to be the main persistence traits in the hill country. The first is reduced hardseededness, or softer seeds, leading to stronger seedling regeneration. In the warm, temperate Australian environment there is a marked decline in hardseededness over summer so that by autumn it has fallen to a low level, allowing most seed to germinate (Collins et al. 1984). However, in cooler climatic conditions of New Zealand, this does not seem to be the case (Lucas et al. 2015; Smetham \& Ying 1991), although Chapman and Williams (1990) argued that hard seed plays only a minor role in population regeneration in subterranean clover. They suggested re-establishment of the populations each year was almost solely dependent on seed inputs during the previous spring. The second trait is late flowering, resulting in a longer period of vegetative production in the field (Chapman \& Williams 1990; Smetham \& Jack 1995). The third trait is the degree of burr burial. This is an important trait as burial protects the seeds in dry conditions where the hook structures of peduncle contract and help to draw the burr into the ground 
(Nichols et al. 2013; Smetham 2003; Yates 1958). While high burr burial will be useful for farmers who want subterranean clover to regenerate year after year in the field, it is potentially a negative trait for seed growers because it impedes seed harvest.

Currently there are 45 registered cultivars of subterranean clover in Australia with a broad range of flowering time and hardseededness (Nichols et al. 2013). Microsatellite DNA markers have been used to discriminate 41 of these cultivars at a single seed level (Ghamkhar 2014). These markers have also been successfully used to investigate associations with important traits such as hardseedness, based on data from two $\mathrm{F}_{2}$ (second generation) populations (Ghamkhar et al. 2012).

Historically, the most widely used cultivars in New Zealand are Mount Barker, Woogenellup, Tallarook and, less frequently, Riverina. However, an accurate trait and climate match study may result in better cultivar selection from the wider pool of available cultivars. Further, the core collection of subterranean clover germplasm (Ghamkhar et al. unpublished data) can be used as a important resource to find accessions with potential adaptation to New Zealand's hill country (Nichols et al. 2016).

Another promising annual inbreeding pasture legume for hill country is biserrula (Biserrula pelecinus ). However, there are strict regulatory requirements that must be satisfied before introducing it into field experiments (Nichols et al. 2016). A core collection of 30 accessions of this species has been developed (Ghamkhar et al. 2013). This provides a broad diversity for discovering germplasm with potential adaptation to summer dry hill country environments.

The aim of the study reported here was to analyse genetic variation among cultivars and accessions of subterranean clover and biserrula, respectively, in the context of traits known to be of importance for New Zealand hill country. Selected attributes, which have been previously identified as being desirable in hill country are also explored in current cultivars/ germplasm. These results will provide valuable information for future cultivar development for the targeted regions.

\section{Methods}

\section{Plant material}

Data were obtained from sub clover and biserrula material used by Faithfull (2008), Banik et al. (2013) and Ghamkhar et al. (2013), briefly described below.

\section{Subterranean clover populations}

Two $\mathrm{F}_{2}$ populations, 92S05 and 92S80 (Table 1) (Ghamkhar et al. 2012), and their parents were sown in a glasshouse and transplanted into the field at Medina Research Station, Western Australia $\left(32.23^{\circ} \mathrm{S}\right.$, $\left.115.80^{\circ} \mathrm{E}\right) 6$ weeks after sowing.

\section{Seed preparation and screening in subterranean clover} Seeds were counted using a Contador seed counter (Pfeuffer GmbH, Kitzingen, Germany) into three replicates of 100 seeds. Screening of hardseededness was conducted in the laboratory using the method of Quinlivan (1961), which is designed to simulate the conditions of seed on the soil surface during summer in the Western Australian wheatbelt. Although the absolute amount of seed softening under this system is likely to be much higher than under New Zealand field conditions, other studies comparing field and laboratory seed softening (Norman et al. 2006) suggest the relative differences between varieties are likely to be valid in New Zealand. In brief, seeds were immersed in water and ice cube trays at $15^{\circ} \mathrm{C}$ for $48 \mathrm{hrs}$. Imbibed (soft) seeds were removed and the remaining hard seeds were placed in a cabinet with a diurnally fluctuating temperature range of $15 / 60^{\circ} \mathrm{C}$. Germination tests were conducted at weeks 8 and 16 . Final hardseed percentages were calculated as per Equation 1: Final hardseed (\%)= Hard seed remaining / (Initial seed - Initial soft seed)

\section{Molecular markers and subterranean clover cultivars} Burrs of 34 cultivars (Table 2) grown under irrigated, well-fertilised conditions were collected from $1 \mathrm{~m}$ rows at South Perth, Western Australia $\left(31.98^{\circ} \mathrm{S}\right.$, $\left.115.86^{\circ} \mathrm{E}\right)$. DNA was extracted from fresh leaf samples at a three-leaf stage or older of 24 cultivars using a Nucleon PhytoPure Plant DNA Extraction Kit (GE Healthcare, Buckinghamshire, UK). A total of 25 SSR primers (Ghamkhar et al. 2012) were used to test their

Table 1 Characteristics of the F2 populations $92 \mathrm{~S} 05$ and $92 \mathrm{~S} 80$ and their parents.

\begin{tabular}{|c|c|c|c|c|}
\hline \multirow[t]{2}{*}{ Character } & \multicolumn{2}{|c|}{ Population 92S05 (size: 214) } & \multicolumn{2}{|c|}{ Population 92S80 (size 221) } \\
\hline & Denmark & DGI007 & Woogenellup & Daliak \\
\hline Origin & Sardinian ecotype & Italian ecotype & Naturalised WA strain & Naturalised WA strain \\
\hline Status & Cultivar & - & Cultivar & Cultivar \\
\hline Flowering time (days) & 142 & 86 & 130 & 98 \\
\hline Hardseededness $(0-10)$ & 2 & 8 & 1 & 7 \\
\hline
\end{tabular}


discrimination power among the 24 cultivars. Each set of cultivars and primers were run through a PCR cycle as follows: $94^{\circ} \mathrm{C}$ for 5 minutes and then 35 cycles of $94^{\circ} \mathrm{C}$ for $50 \mathrm{~s}, 60^{\circ} \mathrm{C}$ for $30 \mathrm{~s}$ and $72^{\circ} \mathrm{C}$ for $50 \mathrm{~s}$.

\section{Biserrula}

Data for flowering time of 30 accessions of biserrula were obtained in the field and annual rainfall was recorded from the original collection site (Ghamkhar et al. 2013).

Table 2 List of 34 subterranean clover cultivars and their scores for hardseededness (HS, 1 (soft) - 10 (hard)), burr burial (BB, 1 (weak) - 9 (strong)), and flowering time (FT, in days measured in Perth from an early May sowing) (Faithful 2008; Nichols et al. 2013).

\begin{tabular}{|c|c|c|c|c|}
\hline Cultivar & Subspecies & HS & BB & FT \\
\hline Antas* & brachycalycinum & 4 & 1 & 134 \\
\hline Bacchus Marsh* & subterraneum & 1 & 2 & 132 \\
\hline Clare & brachycalycinum & 2 & 1 & 130 \\
\hline Coolamon* & subterraneum & 7 & 7 & 132 \\
\hline Daliak $^{*}$ & subterraneum & 7 & 7 & 98 \\
\hline Dalkeith & subterraneum & 9 & 9 & 97 \\
\hline Denmark & subterraneum & 2 & 5 & 142 \\
\hline Dinninup* & subterraneum & 7 & 7 & 114 \\
\hline Dwalganup* & subterraneum & 7 & 7 & 83 \\
\hline Esperance & subterraneum & 5 & 6 & 120 \\
\hline Geraldton & subterraneum & 8 & 7 & 93 \\
\hline Gosse & yanninicum & 4 & 5 & 126 \\
\hline Goulburn & subterraneum & 6 & 5 & 143 \\
\hline Green Range* & subterraneum & 4 & 4 & 128 \\
\hline Izmir & subterraneum & 10 & 7 & 78 \\
\hline Junee & subterraneum & 6 & 6 & 126 \\
\hline Karridale & subterraneum & 2 & 6 & 139 \\
\hline Larisa & yanninicum & 2 & 6 & 140 \\
\hline Leura & subterraneum & 2 & 5 & 147 \\
\hline Losa* $^{*}$ & subterraneum & 5 & 8 & 97 \\
\hline Meteora & yanninicum & 6 & 5 & 148 \\
\hline Mount Barker & subterraneum & 1 & 3 & 137 \\
\hline Napier & yanninicum & 6 & 6 & 140 \\
\hline Northam & subterraneum & 7 & 9 & 78 \\
\hline Nuba & brachycalycinum & 4 & 1 & 146 \\
\hline Nungarin* & subterraneum & 10 & 6 & 77 \\
\hline Riverina & yanninicum & 4 & 6 & 119 \\
\hline Rosedale & brachycalycinum & 8 & 1 & 114 \\
\hline Seaton Park & subterraneum & 6 & 7 & 110 \\
\hline Trikkala & yanninicum & 2 & 6 & 112 \\
\hline Urana & subterraneum & 10 & 7 & 104 \\
\hline Woogenellup & subterraneum & 1 & 3 & 130 \\
\hline Yarloop* & yanninicum & 2 & 6 & 110 \\
\hline York & subterraneum & 9 & 5 & 110 \\
\hline
\end{tabular}

${ }^{*}$ Cultivars not used in the molecular analysis

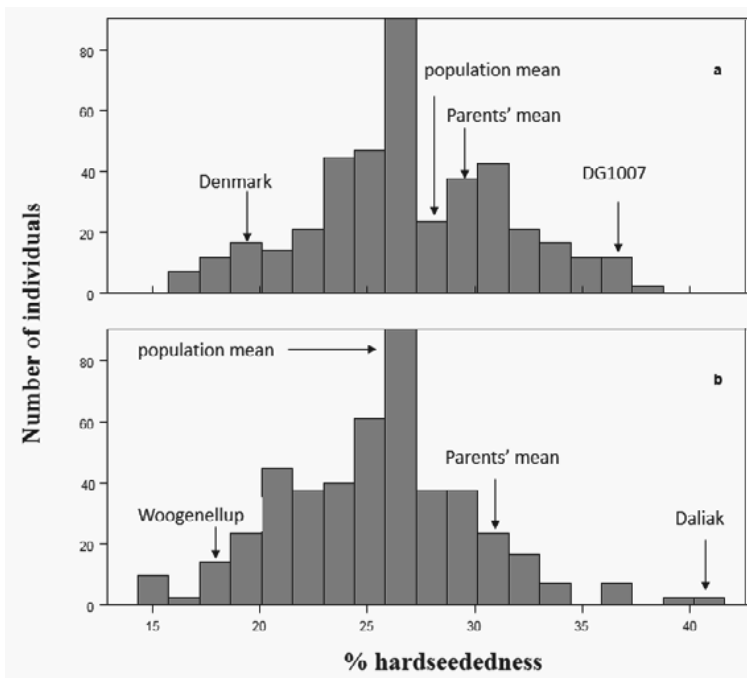

Figure $1 \%$ hardseededness in the two populations of subterranean clover: a) population 92S05, b) population $92 \mathrm{~S} 80$.

Other phenotypic data were obtained from the same accessions in the glasshouse (Banik et al. 2013) (Table 3). The geographical and agro-morphological traits of each accession were categorised as below. Annual rainfall: low: $\leq 350 \mathrm{~mm}$, medium: $>350$ and $<550 \mathrm{~mm}$, high: $\geq 550$ $\mathrm{mm}$. Early flowering: $\leq 77$ days, mid-flowering: $>77$ and $<120$ days, and late flowering: $\geq 120$ days. Visual scoring was used for leaflet size and growth habit.

\section{Data analysis}

For the sub clover segregating populations, GENSTAT v. 5.1 statistical package (Rothamsted Experimental Station, UK) was used to generate trait BLUPs, adjusted means for each line and parent, and to compare BLUPs. Histograms were drawn using ' $\mathrm{R}$ ' (R Development Core Team) and $95 \%$ confidence intervals. For the sub clover cultivars and biserrula core collection, principal components analysis (PCA) was conducted using NTSYSpc v. 2.2 (Exeter Software, Setauket, NY) to investigate correlations between traits/variables. Principal coordinate analysis ( $\mathrm{PCoA})$ was used to project hardseededness into the molecular data using NTSYSpc v. 2.2.

\section{Results}

\section{Subterranean clover}

Both sub clover $\mathrm{F}_{2}$ populations showed a broad range of hardseededness. Mean hardseededness of the population 92S05 (26.7\%) was not significantly different $(\mathrm{P}<0.67)$ to the mean of the two parents $(27.9 \%)$. However, in the 92S 80 population, the population mean of $25.4 \%$ was significantly lower $(\mathrm{P}<0.05)$ than the mean of the two parents (29.4\%) (Figure 1). This indicates a tendency towards less hardseededness in population $92 \mathrm{~S} 80$ than in population $92 \mathrm{~S} 05$. 
Hardseededness data was also obtained for all 34 cultivars (Figure 2). The results of PCA enabled us to group 23 cultivars into five main categories and the other 11 as non-categorised, based on hardseededness, flowering time and burr burial (Figure 3). The categories were as follows: a late flowering group of ssp. brachycalycinum with weak seed burial; a late flowering group from Sardinia (although Mt Barker is a naturalized strain from South Australia, but its preAustralian origin is unknown); a group of soft seeded and late flowering cultivars; a group of early flowering West Australian cultivars with strong seed burial; and a group of belonging to ssp. yanninicum.

Results from PCoA suggested that four molecular markers may be associated with hardseededness based on their reasonable association with hardseeded cultivars (Figure 4).

\section{Biserrula}

A PCA analysis of five variables in biserrula identified five distinct groups in its core collection. These groups were categorised as: accessions with small leaves, prostrate habit, and mid flowering time; accessions from medium to high rainfall regions; early flowering accessions; accessions with large leaves, late flowering time and Moroccan origin, and accessions from low to medium rainfall regions with mid to late flowering time (Fig. 5). No significant correlation was found among the studied traits.

Table 3 Country of origin and agro-morphological traits of accessions of the biserrula core collection (Banik et al. 2013; Ghamkhar et al. 2013).

\begin{tabular}{|c|c|c|c|c|c|c|c|}
\hline Number & Name & Origin & Annual & Rainfall (mm) & $=T^{*}$ (days) & Leaflet size & Growth habit \\
\hline 1 & cv. Casbah & Morocco & & 450 & 105 & Large & Prostrate \\
\hline 2 & cv. Mauro & Italy & & 450 & 116 & Medium & Prostrate \\
\hline 3 & 2004ERI1PEL & Eritrea & & 450 & 56 & Medium & Semi-prostrate \\
\hline 4 & 2004ERI37PEL & Eritrea & & 450 & 49 & Small & Semi-prostrate \\
\hline 5 & 2004ERI38PEL & Eritrea & & 550 & 54 & Medium & Semi-prostrate \\
\hline 6 & 2004ERI56PEL & Eritrea & & 600 & 52 & Medium & Semi-prostrate \\
\hline 7 & 91FRA4PEL & France & & 650 & 125 & Large & Semi-prostrate \\
\hline 8 & 139026 & Greece & & 450 & 117 & Medium & Prostrate \\
\hline 9 & 139049.2 & Greece & & 650 & 98 & Medium & Prostrate \\
\hline 10 & GEH71PEL & Greece & & 450 & $>77$ & Large & Prostrate \\
\hline 11 & GEH77PEL & Greece & & 450 & $>77$ & Large & Prostrate \\
\hline 12 & 139058 & Greece & & 800 & 124 & Large & Prostrate \\
\hline 13 & 2005GRC77PEL & Greece & & 450 & 117 & Large & Prostrate \\
\hline 14 & 2006ISR20PEL & Israel & & 700 & 120 & Medium & Prostrate \\
\hline 15 & $143267 a A$ & Italy & & 600 & 119 & Medium & Prostrate \\
\hline 16 & $143267 \mathrm{bA}$ & Italy & & 600 & 119 & Large & Prostrate \\
\hline 17 & $143464 \mathrm{~A}$ & Italy & & 400 & 106 & Large & Prostrate \\
\hline 18 & 143467 & Italy & & 450 & 117 & Medium & Prostrate \\
\hline 19 & $143469 \mathrm{~A}$ & Italy & & 550 & 122 & Large & Prostrate \\
\hline 20 & 143474 & Italy & & 300 & 118 & Small & Prostrate \\
\hline 21 & 93ITA45PELA & Italy & & 550 & 121 & Small & Prostrate \\
\hline 22 & $138972 A$ & Morocco & & 400 & 117 & Large & Prostrate \\
\hline 23 & 139362 & Morocco & & 250 & 111 & Medium & Prostrate \\
\hline 24 & 139363 & Morocco & & 250 & 123 & Medium & Prostrate \\
\hline 25 & 2006MAR22PEL & Morocco & & 550 & 111 & Large & Semi-prostrate \\
\hline 26 & 2006MAR29PEL & Morocco & & 250 & 115 & Medium & Prostrate \\
\hline 27 & $143415 \mathrm{~A}$ & Spain & & 350 & 116 & Large & Prostrate \\
\hline 28 & 2004ESP19PEL & Spain & & 150 & 82 & Large & Semi-prostrate \\
\hline 29 & 2004ESP39PEL & Spain & & 400 & 130 & Large & Prostrate \\
\hline 30 & 2004ESP64PEL & Spain & & 450 & 146 & Medium & Prostrate \\
\hline
\end{tabular}




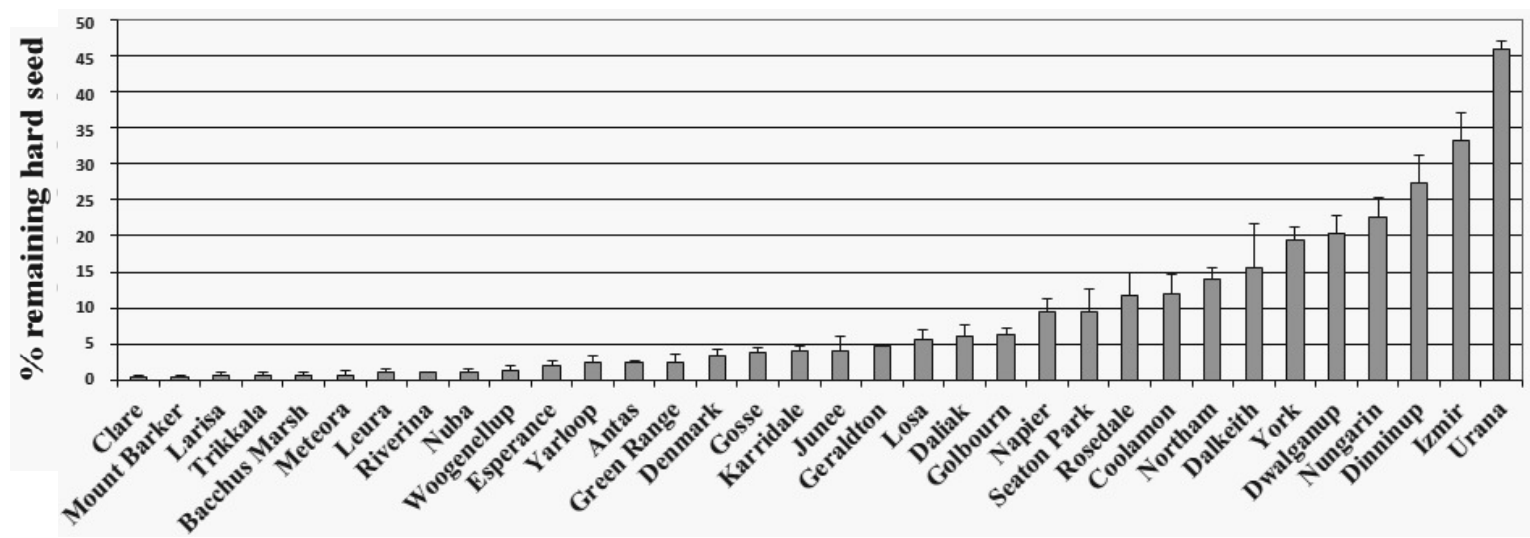

Cultivar

Figure $2 \%$ hard seed remaining after 16 weeks in subterranean clover cultivars.

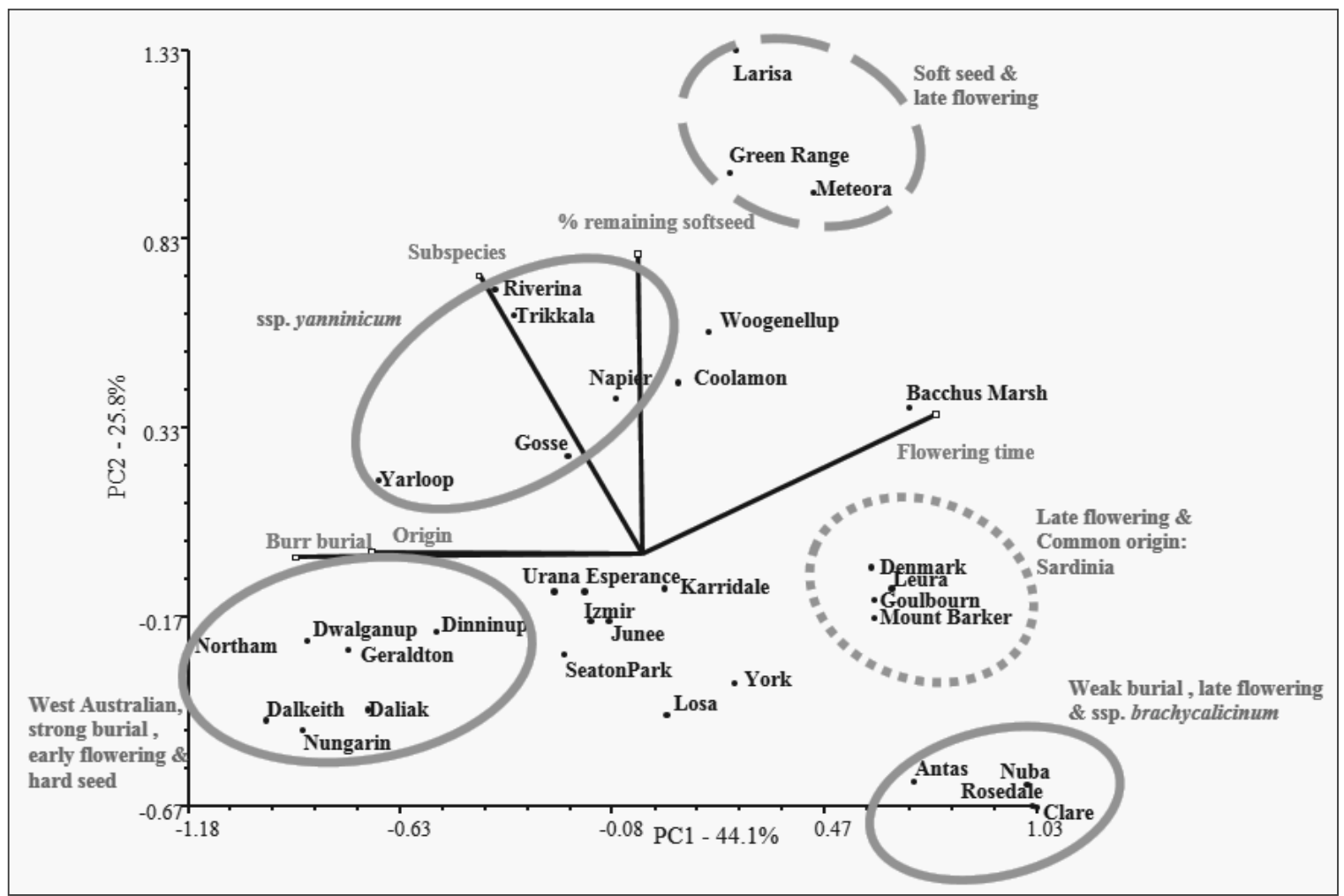

Figure 3 Principal components analysis of agronomic data and categorisation of subterranean clover cultivars with percentage of variation explained by each principal component. The dashed ellipse highlights cultivars with soft seeds and late flowering features. The dotted ellipse highlights cultivars with late flowering and Sardinian origin. Traits of these two groups might potentially be useful in hill country in the future.

\section{Discussion}

\section{Subterranean clover}

In subterranean clover, high levels of hardseededness impede optimal growth in the summer dry hill country due to poor seedling germination. Hardseededness appears to be a polygenic trait based on relatively normal distribution of data along with evident grouping. Salisbury \& Halloran (1983) and Ghamkhar et al. (2012), also showed that hardseededness to be a polygenic trait. Further investigation into the data set showed evidence of transgressive segregation (formation of extreme phenotypes) in both populations, by the number of lines showing lower $\%$ hardseededness than the more softseeded parent (cv Denmark in 92S05 and cv Woogenellup in 92S80). Transgressive segregation for hardseededness was also found by Rieseberg et al. (1999).Transgressive 


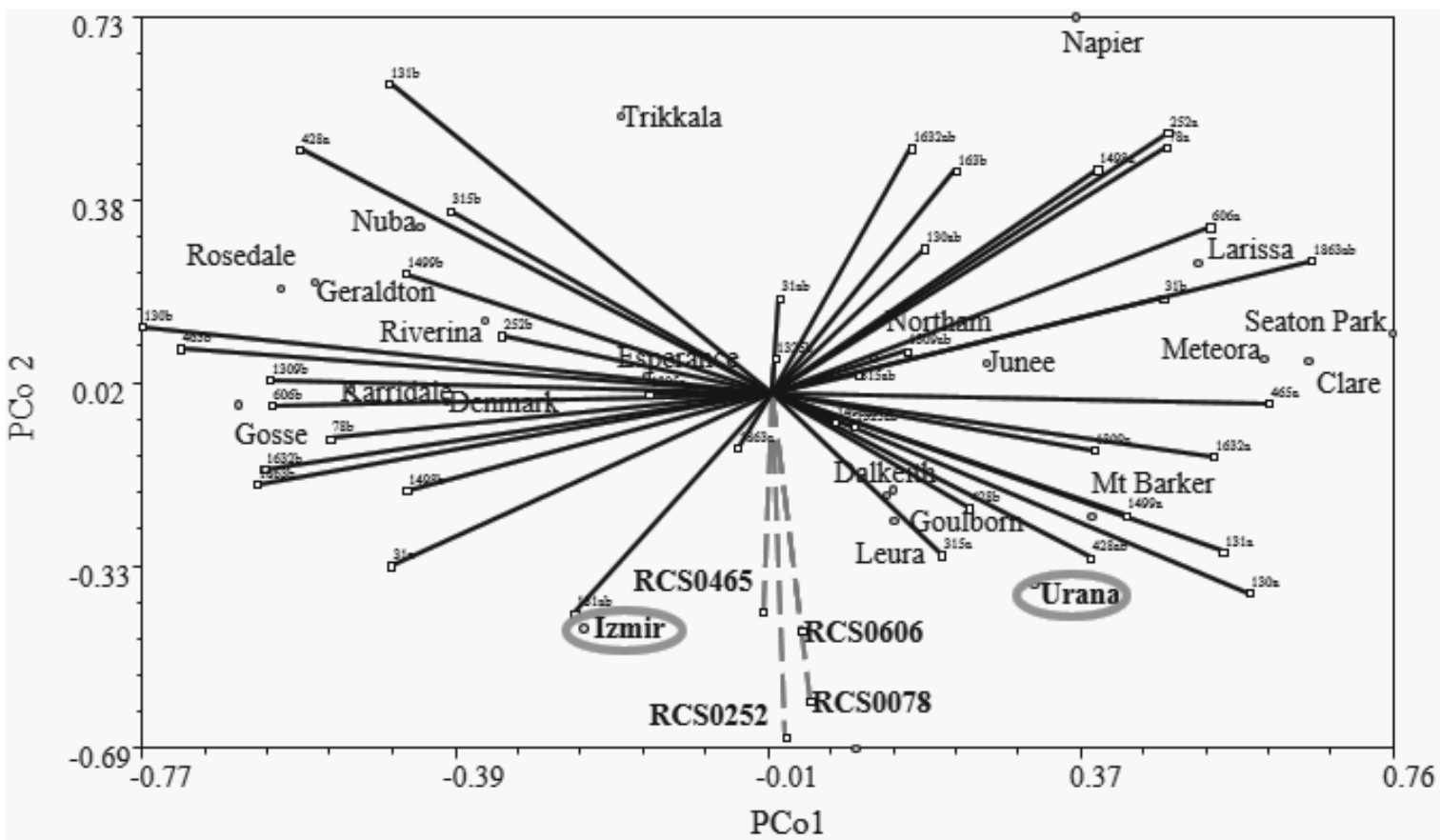

Figure 4 Principal coordinate analysis of molecular markers and cultivars. Cultivars Urana and Izmir are the most hardseeded cultivars among the 34 cultivars studied.

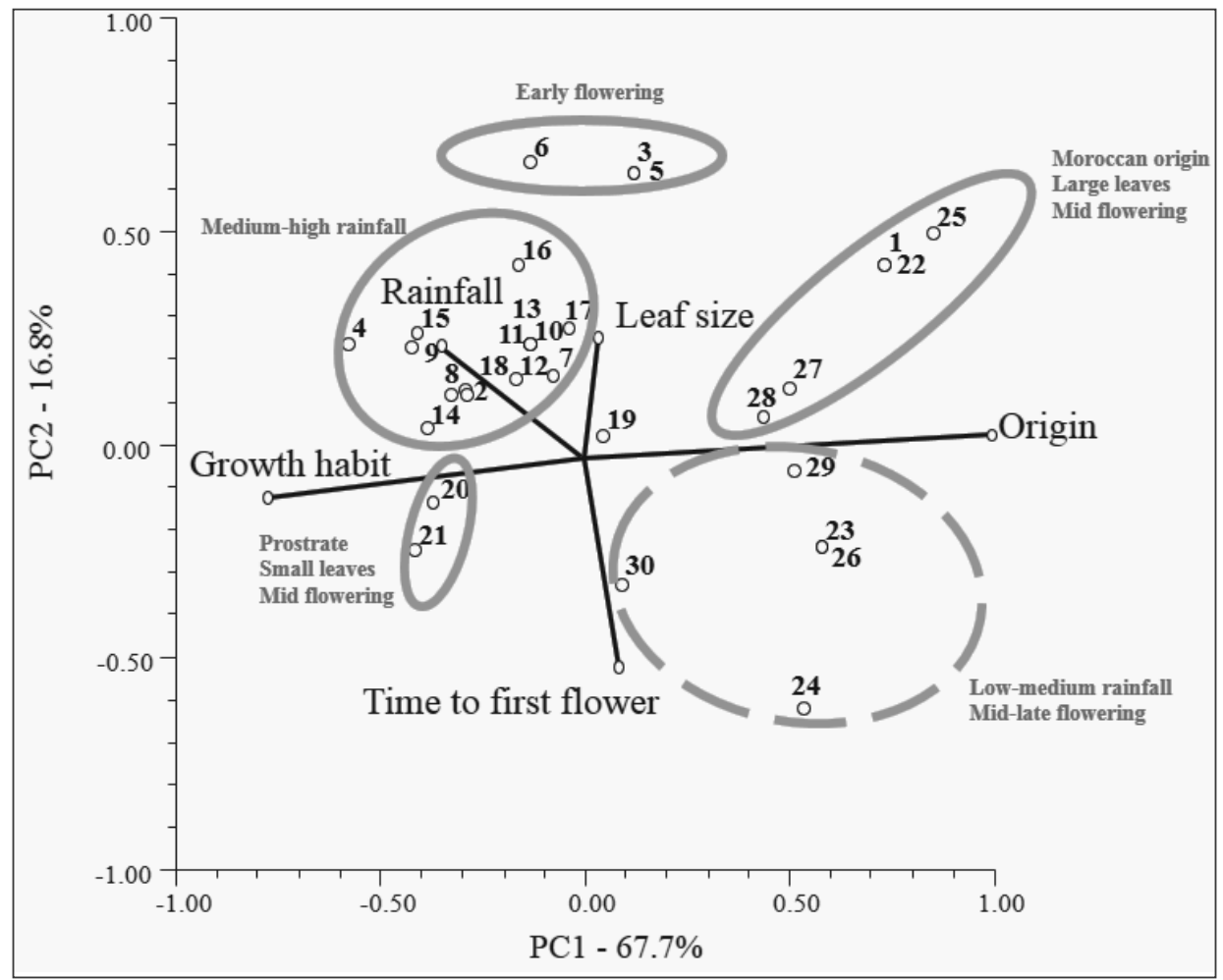

Figure 5 Principal components analysis of agronomic and ecogeographic data and categorisation of accessions with percentage of variation explained by each principal component. The dashed ellipse suggests cultivars most suitable for New Zealand hill country summer dry climate. 
phenotypes in segregating hybrid populations reported here may have been caused by epistatic effects or overdominance. If significant, these heterotic effects could be used in the development of hybrids. The significant difference between the parent and population means in population $92 \mathrm{~S} 80$ suggests that softseededness is a dominant trait, supporting Kilen \& Hartwig (1978) finding. Dominance is difficult to measure in a polygenic trait, however, this significant variation indicates that there may be major genes having a dominant effect, influencing the distribution of the population mean. Estimating the magnitude of additive genetic variation for hardseededness in both populations will provide a basis for future design of breeding strategies.

Currently, two main cultivars, Mount Barker and Tallarook, are widely naturalised in New Zealand's hill country (Lucas et al. 2015; Macfarlane \& Sheath 1984; Smetham 2003). These cultivars were introduced decades ago and in the case of Mount Barker, up to 90 years ago (Saxby 1956). However, in Australia, Mt Barker has poor persistence in summer dry areas, while Tallarook is susceptible to disease (subterranean clover stunt virus (SCSV)) (Nichols et al. 2013) and has high formononetin content, which can cause ewe infertility in clover-dominant swards. Therefore, in Australia, Mount Barker has been replaced by cultivars Leura and Denmark (and more recently by Rosabrook), and Tallarook by Leura. Woogenellup and Riverina are two other cultivars that more recently have been tried in the hill country, but Riverina is much earlier flowering than the other three and also belongs to subspecies yanninicum, with no tolerance to drought.

Any future cultivar for New Zealand's winter wet hill country must have traits similar to the common traits of the group of Larisa, Green Range and Meteora in Figure 3 ; i.e. softseededness and late flowering. However, this is not a cultivar recommendation and by no means suggests that these cultivars are the best for New Zealand's hill country in their current form. The second group of interest may be the late flowering cultivars from Sardinia comprising Denmark, Goulburn, Leura and Mount Barker, although the origin of Mount Barker is not known. These cultivars have an average to strong seed burial and Goulburn is a hardseeded cultivar. Denmark and Leura were also recommended by Widdup \& Pennell (2000) for their late-flowering, small leaves, dense crowns and tolerance of moderatehigh grazing pressure traits. The third group, comprises cultivars Antas, Nuba, Rosedale and Clare all belonging to subspecies Brachycalycinum and having a weaker burr burial, which might be of potential interest to seed companies, and late flowering time. Further research into this group might help in developing cultivars with easier seed harvest while having minor effect on persistence. Some newer cultivars not studied here should also be tested in New Zealand.

Flowering time in subterranean clover is highly heritable and also polygenically determined, with additive effects accounting for most of the variance (Davern et al. 1957; Salisbury et al. 1987). Dominance for earliness was observed by Salisbury et al. (1987), while transgressive segregation towards earlier flowering was reported by Ghamkhar et al. (2012).

When a breeding programme is developed to address the regional needs of the hill country for specific cultivar(s), the molecular markers identified in this study and also marker loci in the genomic regions identified by Ghamkhar et al. (2012) will prove useful. However, it will require further studies to confirm the association of these markers to hardseededness and/or the percentage of remaining hard seeds. Such markers would be of value for screening progenies of crosses for hardseededness to facilitate time and cost efficiencies in cultivar development.

The genetics of burr burial is not well known and is still an unexplored area of research. Support from seed companies to find a balance between easier seed harvest and quality seed production and persistence will initiate genetic and phenotyping studies on the proposed candidate groups and the core collection of subterranean clover for future cultivar development. However, as the grazing pressure in typical hill country at flowering removes runners and aerial seed, a change in grazing management will be needed to allow nonburying types to set seed. Further studies in the field in New Zealand's diverse hill country will be needed to confirm the suggestions made in this study.

\section{Biserrula}

Initial experiments to identify the most promising lines of biserrula for future cultivar development in New Zealand will need to proceed in contained environments due to quarantine issues. It is not known if there are any soft-seeded types of biserrula. The effect of hardseededness needs to be studied to determine the fit of biserrula in New Zealand. These studies must focus on the group from mid-medium rainfall regions with mid-late flowering time comprising five accessions: 139362, 139363, 2006MAR29PEL, 2004ESP39PEL and 2004ESP64PEL (Figure 5). As in sub clover, there is a second group of interest in biserrula which comprises five accessions from Morocco with large leaves and mid flowering time. This late flowering group will add the large leaf trait to future cultivars.

\section{ACKNOWLEDGEMENTS}

We thank the Australian Research Council for financial support. Richard Snowball from the Department of Agriculture and Food Western Australia (DAFWA) and Bidhyut Banik from the School of Animal Biology, 
University of Western Australia (UWA) collected much of the data for biserrula. Michael Blair, Shenton Park campus (UWA) helped with space and equipment. We also thank Dr Sachiko Isobe from Kazusa DNA Research Institute for providing a list of red clover microsatellite primers.

\section{REFERENCES}

Banik, B.K.; Durmic, Z.; Erskine, W.; Nichols, P.; Ghamkhar, K.; Vercoe, P. 2013. Variability of in vitro ruminal fermentation and methanogenic potential in the pasture legume biserrula (Biserrula pelecinus L.). Crop and Pasture Science 64: 409-416.

Barker, D.; Lancashire, J.; Moloney, S.; Dymock, N.; Stevens, D.; Turner, J.; Scott, D.; Archie, W. 1993. Introduction, production, and persistence of five grass species in dry hill country: 8 . Summary and conclusions. New Zealand Journal of Agricultural Research 36: 61-66.

Chapman, D.; Williams, W. 1990. Evaluation of clovers in dry hill country 8 . Subterranean clover at "Ballantrae", New Zealand. New Zealand Journal of Agricultural Research 33: 569-576.

Charlton, J.; Belgrave, B. 1992. The range of pasture species in New Zealand and their use in different environments. Proceedings of the New Zealand Grassland Association 54: 99-104.

Charlton, J.F.L.; Stewart, A.V. 1999. Pasture species and cultivars used in New Zealand-a list. Proceedings of the New Zealand Grasslands Association 61: 147166.

Collins, W.J.; Francis, C.; Quinlivan, B. 1984. Registered cultivars of subterranean clover-their origin, identification and potential use in Western Australia. Bulletin-Western Australian Department of Agriculture (Australia). no. 4083.

Davern, C.; Peak, J.; Morley, F. 1957. The inheritance of flowering time in Trifolium subterraneum L. Crop and Pasture Science 8: 121-134.

Dodd, M.; Sheath, G.; Tarbotton, I. 1995. Development of subterranean clover (Trifolium subterraneum L.) genotypes for New Zealand pastures 3. Whatawhata production evaluation. New Zealand Journal of Agricultural research 38: 57-63.

Faithfull, T. 2008. Hardseededness and phylogenetic studies in subterranean clover (Trifolium subterraneum L.). University of Western Australia, Perth, Western Australia.

Feldhake, C.; Boyer, D. 1990. Bellani evaporation variation in hill-land pasture. Agricultural and Forest Meteorology 51: 211-222.

Ghamkhar, K. 2014. Development of molecular markers for cultivar identification. Commercially sensitive Report to RIRDC Report No. PRJ-008404. Rural Industries Research and Development Corporation.
Ghamkhar, K.; Isobe, S.; Nichols, P.G.; Faithfull, T.; Ryan, M.H.; Snowball, R.; Sato, S.; Appels, R. 2012. The first genetic maps for subterranean clover (Trifolium subterraneum L.) and comparative genomics with $T$. pratense $\mathrm{L}$. and Medicago truncatula Gaertn. to identify new molecular markers for breeding. Molecular Breeding 30: 213-226.

Ghamkhar, K.; Revell, C.; Erskine, W. 2013. Biserrula pelecinus $\mathrm{L}$--genetic diversity in a promising pasture legume for the future. Crop and Pasture Science 63: 833-839.

Kilen, T.; Hartwig, E. 1978. An inheritance study of impermeable seed in soybeans. Field Crops Research 1: 65-70.

Lambert, M.; Roberts, E. 1976. Aspect differences in an unimproved hill country pasture: I. Climatic differences. New Zealand Journal of Agricultural Research 19: 459-467.

Lucas, R.; Mills, A.; Wright, S.; Black, A.; Moot, D. 2015. Selection of sub clover cultivars for New Zealand dryland pastures. Journal of New Zealand Grasslands 77: 203-210.

Macfarlane, M.; Sheath, G. 1984. Clover-what types for dry hill country. Proceedings of the New Zealand Grassland Association 46: 140-150.

Maxwell, T.M.L.R.; Moir, J.L.; Edwards, G.R. 2010. Influence of environmental factors on the abundance of naturalised annual clovers in the South Island hill and high country. Proceedings of the New Zealand Grassland Association 72: 165-169.

Nichols, P.; Foster, K.; Piano, E.; Pecetti, L.; Kaur, P.; Ghamkhar, K.; Collins, W. 2013. Genetic improvement of subterranean clover (Trifolium subterraneum L.). 1. Germplasm, traits and future prospects. Crop and Pasture Science 64: 312-346.

Nichols, S.N.; Crush, J.R.; Eady, C.; Faville, M.; Ghamkhar, K.; Woodfield, D.W. 2016. Future forage plants for hill country systems. Grasslands Research and Practice Series 16: 233-242.

Norman, H.; Smith, F.; Nichols, P.; Si, P.; Galwey, N. 2006. Variation in seed softening patterns and impact of seed production environment on hardseededness in early-maturing genotypes of subterranean clover. Crop and Pasture Science 57: 65-74.

Radcliffe, J.E.; Lefever, K. 1981. Aspect influences on pasture microclimate at Coopers Creek, North Canterbury. New Zealand Journal of Agricultural Research 24: 55-56.

Rieseberg, L.H.; Archer, M.A.; Wayne, R.K. 1999. Transgressive segregation, adaptation and speciation. Heredity 83: 363-372.

Salisbury, P.; Aitken, Y.; Halloran, G. 1987. Genetic control of flowering time and its component processes in subterranean clover (Trifolium subterraneum L.). Euphytica 36: 887-902. 
Saxby, S. 1956. The history of subterranean clover in New Zealand. New Zealand Journal of Agriculture 92: 518-527.

Smetham, M.; Jack, D. 1995. Herbage production under grazing, of some subterranean clover lines compared with lucerne. Proceedings of the $25^{\text {th }}$ Agronomy Society of New Zealand. pp. 69-76.

Smetham, M.; Ying, C.W. 1991. Establishment of subterranean clover (Trifolium subterraneum L.) in New Zealand 1. Hardseededness and autumn germination. New Zealand Journal of Agricultural Research 34: 31-44.
Smetham, M.L. 2003. A review of subterranean clover (Trifolium subterraneum L.): its ecology, and use as a pasture legume in Australasia. Advances in Agronomy 79: 303-350.

Suckling, F.; Forde, M.; Williams, W. 1983. Naturalised subterranean clover in New Zealand. New Zealand Journal of Agricultural Research 26: 35-43.

Widdup, K.; Pennell, C. 2000. Suitability of new subterranean clovers in the Canterbury region. Proceedings of the New Zealand Grassland Association 62: 161-166.

Yates, J. 1958. Seed-setting in subterranean clover (Trifolium subterraneum L.). II. Strain-environment interactions in single plants. Crop and Pasture Science 9: 745-753. 
